\title{
Birleşik Krallık’taki Göç Karşıtt Söylemlerin Brexit Sürecine Etkisi
}

\author{
Murat Çolak' ${ }^{1}$
}

\author{
Özge Bozkaya² ${ }^{2}$
}

\section{Öz}

Birleşik Krallık'ta Haziran 2016'da gerçekleştirilen referandum sonucuna göre, Avrupa Birliği'nden "ayrılma taraftarlarının" oranı daha ağır basmış ve bu sürecin ardından Avrupa bütünleşmesinin geleceğine ilişkin tartş̧malar farklı bir boyutta ele alınmaya başlamıştır. Avrupa şüpheciliğinin belirgin olduğu yerlerden biri olan Birleşik Krallık'ta referandum sonucunda $\% 51,9^{\prime}$ luk oranla Avrupa Birliği'nden ayrılma yönünde oy kullanılması şaşırtıcı bir resim çizmemekteyken, ayrılma kararında göçmen karşıt parti söylemlerinin oldukça etkili olması ilginç bir tabloya işaret etmektedir. Çalışmada, Brexit sürecinde göçmen karşıtı söylemlerin hangi derecede etkili olduğuna yanıt aranmakta ve çalışma literatüre dayanarak ele alınmaktadır. Bu anlamda, göçmen karşıtlığının araçsallaştrıımasında önemli bir örnek sunan ve sert Avrupa şüphecisi olan Birleşik Krallık Bağımsızlık Partisi'nin süreçteki söylemleri üzerinde yoğunlaşılmaktadır. Birlik olma anlayışında çokkültürlülük vurgusu artı̧̧ gösterse de, göçmenlerin Avrupa Birliği üye devletlerinde ekonomik ve sosyal anlamda bir yük oluşturduğu üzerinde tezlerin sunulması ve göçmen karşıtlığının etki alanının genişletilmesi konusunda Brexit süreci somut bir çıkt sunmaktadır.

\section{Anahtar Kelimeler}

Avrupa Birliği • Göç • Brexit • Göç karşıtt söylemler • Avrupa şüpheciliği • Birleşik Krallık bağımsızlık partisi (UKIP)

1 Sorumlu Yazar: Murat Çolak (Doç. Dr.), Dokuz Eylül Üniversitesi, İktisadi ve İdari Bilimler Fakültesi, Çalışma Ekonomisi ve Endüstri İlişkileri Bölümü, Yönetim ve Çalışma Psikolojisi Anabilim Dalı, İzmir, Türkiye. Eposta: m.colak@deu.edu.tr

2 Özge Bozkaya (Doktora Öğrencisi), YÖK 100/2000 Göç Çalışmaları Bursiyeri, Dokuz Eylül Üniversitesi, Avrupa Birliği Anabilim Dalı, Avrupa Çalışmaları Programı, İzmir, Türkiye. Eposta: ozgebozkaya5@gmail.com

Atıf: Çolak, M. ve Bozkaya, Ö. (2018). Birleşik Krallık’taki göç karşıtı söylemlerin brexit sürecine etkisi. Sosyal Siyaset Konferansları Dergisi, 75, 185-209. http://dx.doi.org/10.26650/jspc.2018.75.0013 


\title{
The Impact of Anti-Immigration Discourses in the United Kingdom on the Brexit Process
}

Murat Çolak ${ }^{1}$

\author{
Özge Bozkaya ${ }^{2}$
}

\begin{abstract}
As the referendum held in the United Kingdom (UK) in June 2016, the proportion of "leavers" was much higher than "remainers". Since the referendum, the debate about the future of the European Union (EU) has progressed into a different dimension. The effectiveness of anti-immigrant discourses from political parties points to a very interesting scene. However, it was not surprising that $51.9 \%$ of the citizens of UK voted to leave the EU as a result of the referendum, where European skepticism was evident. Based on the literature, this article tries to find an answer as to what extent anti-immigrant discourses can widen their influence. In this sense, it focuses on the discourses of the hard Eurosceptic United Kingdom Independence Party (UKIP), which presents an example regarding the instrumentalization of the opposition to immigration. Although there is an increase in the emphasis on multiculturalism, in the sense of being a part of the Union, the Brexit process is a tangible outcome with respect to the portrayal of immigrants as an economic and social burden, and it is an expansion of the sphere of influence of anti-immigration sentiments.
\end{abstract}

1 Corresponding author: Murat Çolak (Asst. Prof.), Dokuz Eylul University, Faculty of Economics and Administrative, Department of Labor Economics and Industrial Relations, Izmir, Turkey. Email: m.colak@deu.edu.tr

2 Özge Bozkaya (PhD Student), Council of Higher Education 100/2000 Migration Studies Scholarship, Dokuz Eylul University, 28/5000 Department of European Union, European Studies Program, Izmir, Turkey. Email: ozgebozkaya5@gmail.com

To cite this article: Çolak, M. ve Bozkaya, Ö. (2018). The impact of anti-immigration discourses in the United Kingdom on the Brexit process. Sosyal Siyaset Konferans/arı Dergisi, 75, 185-209. http://dx.doi.org/10.26650/jspc.2018.75.0013 


\section{Extended Summary}

According to the referendum held in the United Kingdom (UK) in June 2016, the proportion of "leavers" was much higher. Since the referendum, the debate about the future of the European Union (EU) has progressed into a different dimension. In total, 51.9\% of the citizens of UK voted to leave the EU as a result of the referendum where European skepticism was evident. This led to some doubts about the future integration model of the EU. In this period, many factors were observed as the impulsion that generated the mode of debates on the future of European integration. One of the most important and controversial factors at the EU level can be identified as migration. Especially after the Syrian Crisis, the number and the types of migrants coming from Syria to other regions were seen as a concern by many states in political, economic, and social terms. Even if the EU's security and border management policies had taken root far before the start of the Syrian Civil War, the Syrians who escaped from the civil war have increased the security concerns of member states to the highest levels. In parallel with the increase of security concerns, the perception of the EU regarding migrants exists as a controvertible subject at a political level because of the differentiated approaches of EU members regarding this issue. Anti-immigration discourses have become a very effective form of populist expression in certain policy areas. One of the examples of this style of expression that has gained more ground in recent years can be observed in UK's EU referendum process. In this context, evaluating anti-immigrant discourses in referendum campaigns presents important clues regarding the rise of Eurosceptic trends in the EU.

In this article, discourses on immigration and migrants during the referendum campaigns are presented as one of the main drivers that paved the way for Brexit (Britain-exit). The instrumentalization of the immigrant opposition arose out of debates between the Conservative Party and the United Kingdom Independence Party (UKIP), and this provides an example of the position of migration in the EU. The rise of far-right politics and populist radical discourses are a defined problem that the EU must overcome and the UK referendum process is supposed to be held as a concrete sample regarding this problem. Therefore, as a tool of populist and far-right wing discourses, explaining the anti-immigration aspects in the UK's referendum process is the main aim of this study. In this context, the presentation of the immigrants as an economic and social burden on the EU member states is a critically moot point that questions the future of the EU. So, as a factor that is pushing the discourses of the far-right wing, populists, and anti-immigrant can be defined as a risk for the EU and its normative characterization. This study aims to explain how anti-immigrant discourses can influence the campaign process and to what extent it affected the UK's decision to leave the EU.

According to the literature, Brexit has been held in terms of the process itself, and a future model of European integration is now on the agenda of many scholars 
in terms of the many risks that the EU has confronted. Even if Brexit does not seem like an astonishing step, it is a factor pushing anti-immigrant discourses that draw a considerable scene. Among the member states, UK has been defined as the representative of Eurosceptic tradition for a long time. In the EU, where there has been a developing culture of solidarity among member states in areas such as the Eurozone, the Justice and Home Affairs, and the Schengen Area, the separation of UK politics from the culture of solidarity has been assessed as the axis of European skepticism. When considering UK's isolated preferences in some European level policy areas and its Eurosceptic tendency, we can evaluate Brexit as not being a surprising event. However, anti-immigrant discourses in the process can be evaluated as a challenging dimension. Anti-immigrant discourse has not only widened its influence in the UK's political scene, it has reached a worrisome dimension in many other parts of the EU today. Therefore, analyzing the Brexit process presents a tangible outcome about to what extent anti-immigrant and populist discourses can widen their influence in the European Union. 


\section{Birleşik Krallık’taki Göç Karşıtı Söylemlerin Brexit Sürecine Etkisi}

Birleşik Krallık'ın² 2016 yılında gerçekleştirdiği referandum sonucunda Avrupa Birliği $(A B)$ 'den ayrılma yönünde karar alması, Avrupa bütünleşmesi için yeni bir sürecin başlamasına neden olmuştur. Birleşik Krallık, AB'den daha izole bir politika anlayışı gütmesi ve bütünleşmeye daha şüpheci bir yaklaşım sunması nedeni ile uzun yıllardır tartışma konusu olmuştur. Dolayısı ile ayrılma kararının kendisi beklenmedik bir nitelik sergilemese de, kararın verilmesinde payı olan göç ve göçmenlere bakış analiz edildiğinde ilginç bir tablo ortaya çıkmaktadır. Buna göre, $A B$ ve Birleşik Krallık ilişkileri için yeni bir dönemi başlatan bu referandumun kendisini analiz etmek ve Birleşik Krallık’taki AB şüpheciliğini şekillendiren faktörlerden olan göçmen karşıtı söylemleri irdelemek oldukça önemlidir.

Referandum sürecindeki söylemler, $\mathrm{AB}$ 'den ayrılma ve $\mathrm{AB}$ 'de kalma taraftarlarının oluşturduğu iki kamp arasında şekillenmiştir. Bu söylem şekillendirme sürecinde kamuoyunun göç ve göçmenlere bakışı, kampanyaları belirleyen en etkili faktörlerden biri olmuştur. Özellikle Muhafazakar Parti ve Birleşik Krallık Bağımsızlık Partisi (United Kingdom Independence PartyUKIP) arasında gerçekleştirilen söylem yarışında, göçmen karşıtlığının araçsallaştırılarak bir etki alanı yaratılması, Avrupa' da göçün konumlandırılışı ile ilgili bir örnek sunmaktadır. Ayrıca, referandum sürecinde kullanılan göçmen karşıtı söylemler, Avrupa'nın başa çıkması gereken sorunlar arasında sınıflandırılan aşırı sağın yükselişi ve popülist radikal söylemlerin taban kazanması anlamında bir takım ipuçları vermektedir.

Avrupa'da aşırı sağ partilerin söylemlerinde yer eden göçmenler ve çokkültürlülük konuları, bu partilerin Avrupa bütünleşmesine bakışlarını etkileyen temel faktörler arasındadır. Ayrılık taraftarları ve AB'de kalma taraftarları olmak üzere iki kampın söylemlerinin birbiri ile yarıştığı referandum sürecinde, kampanyaların şekillenmesinde kullanılan en önemli faktörler arasında, göç ve göçmenler bulunmaktadır. Buna göre, Muhafazakar Parti ve Birleşik Krallık Bağımsızlık Partisi arasında öne çıkan yarışta, söz konusu göçmenler olduğunda olumsuz bir yaklaşım benimsenmiş ve göç konusunun bir araç olarak kullanılması, Brexit sürecinin en önemli belirleyicilerinden biri haline dönüşmüştür. Göçmen karşıtı söylemlerin etkinliğinin Avrupa bütünleşmesi anlamında

3 Britanya, İngiltere, Galler ve İskoçya'nın bulunduğu adaya verilen isimdir. Birleşik Krallık ise, Britanya (İngltere, İskoçya ve Galler) ve Kuzey İrlanda'nın dahil olduğu 4 ülkeden oluşan üniter bir devlettir. 
somut bir çıktı yarattığı Brexit'i bu kapsamda analiz etmek oldukça önemlidir. $\mathrm{Bu}$ doğrultuda, çalışmanın temel amacı, Birleşik Krallık referandumu kampanya sürecinde kullanılan göçmen karşıtı söylemlere ve bu söylemlerin etkililik derecesine ilişkin bir yaklaşım geliştirmektir. Çalışma ile göçmen karşıtı söylemlerin kampanya sürecini nasıl yönettiği ve AB'den ayrılma kararının alınmasında hangi boyutta etkili olduğu açıklanmaya çalışıımaktadır.

\section{Birleşik Krallık ve Avrupa Şüpheciliği}

Günümüzde Avrupa şüpheciliği, üye devletler arasında giderek artan bir ivme kazanmakta ve Avrupa Birliği bütünleşme sürecinin farklı senaryolara dayanarak tartışılmasına zemin hazırlayan önemli bir faktör olarak karşımıza çıkmaktadır. Bütünleşmeye şüpheyle yaklaşanların daha belirgin olduğu Birleşik Krallık için “Avrupa şüpheciliği” terimi İngiliz siyasi sözlüğünde ilk olarak Haziran 1986'da The Times'daki bir makaleden yapılan alıntı ile girmiştir (Startin, 2015, s. 312). Özellikle 1990'l1 yıllara gelindiğinde, Avrupa Birliği'nin uluslarüstü boyutu üzerinden sürdürülen tartışmalar, Birleşik Krallık’ta Avrupa şüpheciliğinin daha da zemin kazanmasında etkili olmuştur. Maastricht Antlaşması ile birlikte parasal birlik, sosyal güvenlik ve diş politika gibi alanlarda Birliğe sorumluluk yüklenmesi, uluslarüstü mekanizmanın işletildiği alanların çeşitlilik kazanması ve AB bütünleşmesinin derinleşmesi hususlar1 Avrupa şüphecilerinin söylemlerinde yer eden önemli faktörler halini almıştır (Ermağan, 2012, s.149).

Uluslarüstü mekanizmanın bir gereği olan ulusal egemenliğe ait kimi yetkilerin $\mathrm{AB}$ kurumlarına devri, kuruluşundan bu yana $\mathrm{AB}$ 'de farklı bütünleşme yaklaşımlarının tartışılmasına neden olan bir husustur. Bütünleşmeye güvensizlik ve şüphe ile yaklaşanlar, Avrupa şüpheciliği kavramı ile eş değer tutulmaktadır. Fakat, Avrupa şüpheciliğini, AB karşıtlığı ile aynı anlamda kullanmamak gerektiğinin altını çizmekte fayda vardır (Köroğlu ve Çendek, 2015, s. 198). Bu noktada, Avrupa bütünleşmesi fikri veya AB'ye karş1 olanlar (sert şüpheciler) ve Avrupa bütünleşmesi fikrine karşı olmak yerine bütünleşme sürecine şüpheyle yaklaşanlar (yumuşak şüpheciler) şeklinde iki ayrı sınıflandırma yapmak mümkündür (Taggart ve Szczerbiak, 2002, s. 4). Sert Avrupa şüphecileri yani AB'ye ve Avrupa bütünleşmesine karşı olanlar, AB üyeliğinden ayrılma yanlısı tutum sergileyebilmekteyken; yumuşak Avrupa 
şüphecileri AB'den bazı politika alanlarında ayrılarak yalnızca söz konusu alanlarda karşı bir duruş geliştirmektedir (Taggart ve Szczerbiak, 2002, s. 4). Taggart'a göre Avrupa bütünleşmesi konusunda şüphe ile yaklaşanlar ikiye ayrılmaktadır. Bunlardan ilki, AB bütünleşme modelini oldukça "içerici" bulan şüphecilerdir. Diğer bir deyişle, birbirinden farklı olan faktörleri bir arada tutmaya çalıştığ gerekçesiyle Avrupa bütünleşmesine şüphe ile yaklaşanlar olarak ifade edilebilir. Buna örnek olarak, AB'ye yönelen göçün artış göstermesine karşı olup, bu konuda sorumluluk paylaşmak istemeyen şüpheciler verilebilir (Taggart, 1998, s. 365-366). İkincisi ise, AB'yi bütünleşme modeli olarak "dışlayıcı" bulan şüphecilerdir. Söz konusu şüpheci yaklaşıma göre, dışlama birçok türde gerçekleşebilir. Bir ülke sosyal veya coğrafi anlamda birçok şekilde dışarıda bırakılabilir (Taggart, 1998, s. 366).

Birleşik Krallık'ın şüpheci yaklaşımı ise "geleneksel” olarak tanımlanabilmekte ve tarihsel bir uzantı çerçevesinde değerlendirmeye tabi tutulmaktadır. Özellikle Hindistan, Avustralya, Yeni Zelanda ve Kanada gibi Milletler Topluluğu ülkeleri ile ${ }^{4}$ tarihsel bağlarının olması, bir ada üzerinde konumlanması, Amerika Birleşik Devletleri ile sahip olduğu özel ilişkiler ağı gibi faktörler Birleşik Krallık'ın AB'den daha izole ve bağımsız politikalarını açıklayan argümanlar olarak kullanılmakta ve Avrupa şüpheciliğinde etki eden geleneksel faktörler olarak sunulmaktadır (Daddow, 2013, s. 213). Birleşik Krallık'ın Avrupa Topluluğu'na üyeliğinin kabul edilmesi, üyelik sürecindeki politikalara katılım düzeyi ve $\mathrm{AB}$ üyeliği referandumu neticesinde üyelikten ayrılma taraftarlarının ağır basması, üzerinde durulması gereken önemli süreçleri ifade etmektedir. Çünkü tüm bu süreçler kendi içinde, Birleşik Krallık'ın “izole” olarak ifade edilen imajına ilişkin önemli dinamikleri barındırmaktadır.

İkinci Dünya Savaşı sonrası konjonktürde Avrupa'da ekonomik bir entegrasyon sağlamanın, bölgede barış ve istikrar getireceği fikrinden hareketle oluşturulan Avrupa Ekonomik Topluluğu (AET) ile Birleşik Krallık arasındaki ilişkilere bakıldığında, bu dönemde Birleşik Krallık’ın ekonomik kapasitesinin Topluluk'a ilgisizliğini açıklayan en önemli faktör olduğu görülmektedir.

4 Eski Britanya İmparatorluğu'nun parçası olan devletler ve sonradan dahil olan bazı devletlerle oluşturulan uluslararası bir örgüttür. 53 bağımsız ve egemen devletin gönüllü katılımından oluşmaktadır. Üyelerin 30'u küçük ada devletlerinden oluşmaktadır. Üye devletler, 80'den fazla profesyonel, hükümetlerarası, sivil toplum ve kültürel kuruluşların meydana getirdiği ağ ile destek bulmaktadır. Örgüte en son üye olan devlet ise (2009 yılında) Ruanda'dır. 
1951 yılında Avrupa Kömür ve Çelik Topluluğu'nun kurulması ile birlikte, bölgede İkinci Dünya Savaşı'nın etkilerini kaldıracak bir ekonomik dayanışmanın sağlanmasına Birleşik Krallık'ın başta yeterince ilgi duymamasının temel nedeni, Topluluğun getireceği katkı ile kendi ekonomik kapasitesi arasinda yaptığ 1 bir tercihle alakalıdır (Nugent, 2004, s. 23-24).

1960'larla birlikte ne zaman Avrupa Topluluğu üye devletlerinin ekonomik kazanımları, Birleşik Krallık'ın kazanımlarından yüksek oranda seyretmeye başladı; o zaman Topluluk'a katılım sağlamak Birleşik Krallık için önemli bir hale geldi (Nugent, 2004, s. 24). 1 Ocak 1973 'te gerçekleşen üyeliği ve ilerleyen süreçte, Birleşik Krallık'ın Topluluk politika üretimi ve uygulaması mekanizmasındaki bazı alanlarda uluslarüstü mekanizmaya dahil olmaktan kaçınması, izole bir yaklaşım içinde olduğuna dair argümanları destekleyen başka bir boyutu oluşturmaktadır (Sutherland, 2016, s. 311). Özellikle 1990'lar "Avrupa vatandaşlığı" ve "siyasi birlik" vurgularının yapılması, bütünleşmenin derinleşme boyutunun tartışılması nedenleri ile Birleşik Krallık'ta Avrupa şüphecisi söylemlerin artış gösterdiği bir dönemdir. Bu dönem (Maastricht Antlaşması'nın onaylanması süreci ve sonrası) tüm Avrupa genelinde bütünleşmeyi şüpheci bir eksende ele alan söylemlerin ivme kazanarak yer edindiği bir dönüm noktası olarak değerlendirilmektedir (Serricchio ark., 2013, s. 53).

Avrupa şüpheciliğinin, Birleşik Krallık siyasi arenasında ve $\mathrm{AB}$ genelinde ivme kazanmasına neden olan diğer önemli faktörler Birliğin "en hırslı genişlemesi” olarak dile getirilen 2004 genişlemesinin ve sonrasında 2007 genişlemesinin gerçekleştirilmesi, 2008 krizinin Birlik'i derinden etkilemesi şeklinde sıralanabilir (Epstein ve Jacoby, 2014, s. 1; Startin, 2015, s. 315). Avrupa'da güvenlik ve istikrar sağlanması amacından hareketle, Orta ve Doğu Avrupa ülkelerinin üyeliğinin desteklenmesi anlayışı, Berlin Duvarı'nın yıkılması ve komünist bloğun çöküşü sonrasında bir sorumluluk bilinci ile oluşturulmuştur. Fakat bu anlayış, Avrupa şüphecileri tarafından eleştirilmiştir. Buna göre, Orta ve Doğu Avrupa ülkelerindeki işsizlik ve iş güvenliği sorunlarının boyutu, bu bölgelerden Batı'ya gelmesi muhtemel göçmen akışının Avrupa güvenliğini tehdit edebileceği öngörüsü, Avrupa şüphecilerinin temel argümanları olarak sıralanmıştır (Startin, 2015, s. 315-316).

Daha bütünleşik bir Avrupa anlayışı ile parasal bir Birlik oluşturulması için adımlar atılsa da, 2008 yılında Avrupa'yı vuran ekonomik ve mali kriz, işsizlik, 
sosyo-ekonomik eşitsizlikler, kemer sıkma politikaları ile sonuçlanmış ve "ortak para birimi ve mali bütünleşme süreci” gibi konular Avrupa şüphecilerinin eleştirdikleri temel meseleler haline gelmiştir (Startin, 2015, s. 316). Buna örnek olarak, Birleşik Krallık'ta, Avrupa şüphecisi bir söyleme başvuran ve hatta sert Avrupa şüphecisi olarak nitelendirilen Birleşik Krallık Bağımsızlık Partisi'nin (The United Kingdom Independence Party) lideri olan Nigel Farage'in Euro'nun para birimi olarak kullanılmasını bir başarısızlık olarak değerlendirmesi verilebilir.

Avrupa şüpheciliği üzerinden geliştirilen söylemler, $A B$ 'de popülist radikal sağ partilerin kamu oyundan destek bulmasında etki eden faktörlerdendir. Özellikle 2008 krizi, AB için ekonomik ve mali anlamda bir bunalımın ötesinde bütünleşme sürecinin siyasi tartışmalara yol açtığı bir ortamı da yansıtmaktadır. 2008 krizi ile Avrupa genelinde artan işsizlik, istihdam sorunları, ekonomik ve mali bunalım, göçmenlere karşı geliştirilen söylemler üzerinde de oldukça etkili faktörler olmuştur. Göçmen karşıtlığı söylemlerinin artış gösterdiği bu bunalım sürecinin ardından, 2011 yılında Suriye İç Savaşı'nın patlak vermesi ile Avrupa'ya yönelen Suriyeli akını Avrupa şüphecisi söylemlerin göçmen karşıtlığı üzerinden artış göstermesine neden olmuştur. Birleşik Krallık’ta gözlemlenen "geleneksel” şüpheciliğin, AB'den ayrılma taraftarlarının ağır bastığı $\mathrm{AB}$ referandumu ile somut bir adıma dönüştürülmesi şaşırtıcı bir tablo çizmemektedir. Fakat referandum ve göçmen karşıtı söylemlerin ortak bir zeminde ele alınabileceği bir araştırma alanı oluşturması oldukça önemli ve ilginçtir. Bu doğrultuda, çalışmada göçmen karşıtlığı daha mikro düzeyde ele alınarak, Birleşik Krallık'ın AB referandumu sürecine nasıl etki ettiği açıklanacaktır. Fakat öncelikle Brexit süreci, bu süreci etkileyen faktörler ve sürecin $\mathrm{AB}$ bütünleşmesini nasıl etkilediği izleyen bölümde aktarılmaktadır.

\section{Brexit, Gerekçeleri ve Avrupa Birliği'nin Geleceği}

5 Haziran 1975 yılında Birleşik Krallık'ta Avrupa Topluluğu (AT) 'na yönelik yapılan ilk ulusal referandumda, \%67'lik bir oranla AT'de kalma yönünde oy kullananlar ağır basmıştır. Bu referandum sonucunda AT'dan ayrılma taraftarları ağır basmasa da; referandum, AT'de kalma veya AT'den ayrılma yönünde bir seçim sunması nedeniyle Birleşik Krallık'ın Avrupa şüphecisi olduğuna yönelik argümanları kuvvetlendirmiştir. Birleşik Krallık’ta 23 Haziran 2016 tarihinde AB'ye dair yapılan ikinci referandumda ise, \%51.9'luk oranla 
ayrılık taraftarları ağır basmış ve bir önceki referandumdan farklı bir şekilde hem $\mathrm{AB}$ hem de Birleşik Krallık için yeni bir dönem açılmıştır (Goodwin ve Heath, 2016, s.323-324). Buna göre "Brexit (Britain-exit)" yani Birleşik Krallık'ın AB'den ayrılışı olarak adlandırılan yeni bir süreç AB'nin geleceği ile ilgili bütünleşme senaryolarını gündeme getirmeye başlamıştır.

Çalışmada göçmen karşıtı söylemler üzerinden Brexit sürecini değerlendiren bir anlatım yoluna başvurulsa da, öncelikle bu sürece yol açan faktörlerin bütününe değinmekte fayda vardır. Brexit'e giden yolda popülist söylemlerin zemin kazanmasında en etkili araçlardan biri göç ve göçmenler olarak sunulsa da, süreci birçok faktörün bir araya gelerek yönettiğini unutmamak gerekmektedir. Birleşik Krallık'ın geleneksel şüpheci yaklaşımına neden olan unsurlardan birinin $\mathrm{AB}$ ' deki uluslarüstü mekanizmanın boyutu ile ilişkili olduğu düşünüldüğünde; Brexit'e giden yolda Birleşik Krallık’taki ayrılma taraftarlarının Avrupa Parlamentosu'nun donatıldığı yasal yetkilerden hoşnut olmadıkları söylenmelidir (Scuira, 2017, s. 112). Bu nedenle Brexit sürecine yol açan temel faktörlerden birinin, Birleşik Krallık'taki ayrılma taraftarlarının $\mathrm{AB}$ uluslarüstü mekanizmasına karşı olan geleneksel duruşlarından kaynaklanan egemenlik endişeleri olduğu söylenebilir. Bu durum, Avrupa şüphecilerinin $\mathrm{AB}$ Parlamentosu'nun yetki ve sorumluluğunun bugün ulaştığı boyutu, ulusal çıkarların ve kontrolün kaybı ile ilişkilendirmelerinden kaynaklanmaktadir (Whelan, 2018, s. 1).

2008 krizinin ardından, ekonomik yönetişimin güçlendirilmesinden hareketle Avrupa Komisyonu'nun yetki alanının genişleyerek, AB üye devletlerinin uygulamalarına ilişkin izleme, değerlendirme ve gerekli yükümlülükleri yerine getirmeyen üye devletlere yaptırım uygulama yetkisine sahip olması, bir diğer tartışma alanıdır. Üye devletlerin mali uygulamaları arasında eşgüdüm sağlanmasına hizmet eden Avrupa Yarıyılı ile Komisyon üye devletlerin bütçelerine ilişkin izleme ve tavsiyede bulunma hakkına erişmiştir (Ling, 2016, s. 70). Bu durum ise, Birleşik Krallık'ın parlamenter demokrasi ve geleneksel şüpheci anlayışı ile ters düşmüştür (Ling, 2016, s. 71). 2008 krizinin etkisi ile Birliğin başvurduğu kemer sıkma önlemleri, borç krizinden kaynaklanan nedenlerle Birleşik Krallık’ta sosyal refahı ve vergi politikası düzenlemelerini etkileyecek kısıntılara gidilmesi, AB kurumlarının ekonomi politikalarına ilişkin konumunun güçlendirilmesi, Avrupa Birliği demokrasi açığının 
arttığına dair seslerin yükselmesi, Birleşik Krallık’taki siyasi arenanın AB üyeliği konusunda kutuplaşan yapısı, "göç krizi” adı altında değerlendirilen iç savaştan kaçan Suriyelilerin durumunun Birlik ve üye devletler nezdinde yarattığı yeni güvenlik endişelerinin popülist yaklaşımlara ivme kazandırması gibi faktörler bir araya gelerek Birleşik Krallık’1 referanduma iten temel meseleler olarak yerini almıştır.

Avrupa şüphecilerinin "kazananlar" olarak ifade edildiği referandum sonrasında ise, Birleşik Krallık'taki partiler arasındaki tansiyon artmış ve bu süreç Avrupa genelindeki şüpheci diğer partilerin söylemlerini şekillendiren önemli bir dönemi açmıştır (Goodwin ve Heath, 2016, s. 324). David Cameron Hükümeti döneminde maliye bakanı olarak görev yapan George Osborne'un AB'den ayrılmanın İngiliz ekonomisini olumsuz etkileyeceği ve dönemin ABD Devlet Başkanı Barack Obama'nın ise olası bir ayrılığın Birleşik Krallık'ın dünya sahnesindeki etkisini düşüreceğine dair söylemlerinin de zemin bulduğu bu süreçte, Avrupa şüphecileri ve Avrupa bütünleşmesi yanlılarının geliştirdikleri argümanlar birbirleri ile çarpışmış; iki tarafı karşı karşıya getirmiştir (Menon, 2017, s. 128). Birçok faktörün etkisi ile oluşan bu kutuplaşma, bazı düşünürler tarafından "Brexit savaşı" olarak isimlendirilmekte sınıfların, bölgesel ayrılıkların veya siyasi tarafların ayrışmasından çok köklerini neoliberalizmin yarattığı ayrışmalar ve eşitsizliklerden alan bir süreç olarak ifade edilmektedir (Powell, 2017, s. 226). Bazı düşünürler ise Brexit sürecini Birleşik Krallık’taki AB bütünleşmesi sürecine karşı artan negatif tutumun ve milliyetçiliğin yükselişi ile ilişkilendirmektedir (Sutherland, 2016, s. 312).

Birleşik Krallık'ta yapılan referandumun, AB'deki diğer üye devletler için bir domino etkisi yaratabileceğine dair beklentiler olsa da, bu öngörü gerçekleşmemiştir. Birleşik Krallık’tan sonra AB için referandum gerçekleştiren başka bir üye devlet olmamıştır. Fakat Brexit ile birlikte, AB'deki popülist radikal sağ partilerin yükselişinin ve özellikle geliştirdikleri göçmen ve AB bütünleşmesi karşıtı söylemlerin hangi derecede etkili olabileceğine dair önemli bir resim çizilmiştir (Sutherland, 2016, s. 312). Avrupa'daki merkez sağ ile merkez sol partiler arasında ciddi farklılıklar gözlemlense de, iki tarafin da benzer konular üzerinden karşıt söylemler geliştirdiğini unutmamak gerekmektedir. Bu konulara ise Avrupa bütünleşmesinin geleceği, göç ve küresel ticaret gibi başlıklar örnek verilebilir (Applebaum, 2017, s. 55). 
Avrupa'nın geleceği tartışmalarında itici faktör olan Birleşik Krallık AB referandumundan sonra, 1 Mart 2017'de Avrupa Komisyonu Başkanı Jean Claude Junker, Birliğin durumuna ilişkin konuşmasında (The State of Union) 27 üye devletin dayanışma içinde olacağı daha bütünleşik bir Avrupa mesaj1 vermiş ve yayınlanan Beyaz Kitap'tan bahsetmiştir. Buna göre, Avrupa Birliği'nin geleceği hakkında muhtemel senaryoların çerçevesi çizilmiştir. Bu çerçevede oluşturulan beş senaryonun ise AB'nin geleceğine ilişkin tartışmaları sonlandırmak niyeti ile değil, ortak bir zeminde tartışılmasına ortam hazırlamak için yapıldığının altı çizilmiştir (European Commission, 2018, s. 3).

AB'nin geleceği hakkındaki muhtemel senaryoları konu alan 1 Mart 2017 tarihli Beyaz Kitap'ın yayınlanması ve daha bütünleşik bir Avrupa vurgusu yapılması, Birliğin yaşadığı zorluklarla ilişkilidir (European Commission, 2018, s. 8). Bunlar, küreselleşmenin artış göstermesi, hızla gelişen teknolojinin toplumun ve iş piyasasının üzerinde etki alanını genişletmesi, güvenlik endişelerinin farklı bir boyut kazanması ve popülizmin ivme kazanması şeklinde ifade edilmektedir. Ayrıca Beyaz Kitap’ta, daha rekabetçi, içerici ve dayanıklı bir Avrupa ekonomisine erişmek için ekonomik ve parasal birliğin tamamlanması, üye devletlerin sosyal ve ekonomik uygulamalarının birbirine yaklaştırılması ve avro alanına ilişkin yaşanan sorunların üstesinden gelmenin önemine vurgu yapılmıştır (European Commission, 2018, s. 9; Bakkalcı, 2008). AB için 27 üye devlet ile birlikte dayanışmanın merkezde tutulduğu bir gelecek vurgusu yapılması, eksilecek bir üye devlete yani Birleşik Krallık’ın Brexit sürecine de bir göndermede bulunmaktadır. Zira, bu mesaj, Birleşik Krallık'ın referandum sürecinin AB'nin geleceği için yeni bir dönem başlatt1ğının da altını çizmektedir.

\section{Birleşik Krallık ve Göç}

Birleşik Krallık ve göç arasındaki ilişkiyi analiz etmeden önce, göçün kavramsal çerçevesi üzerinde durmak gerekmektedir. Uluslararası Göç Örgütü’ne göre göç, bir uluslararası sınırı aşan ya da bir ülke içinde gerçekleşen taşınma sürecidir. Süresi, mesafesi, içeriği, kapsamı ve nedenleri ne olursa olsun insan hareketlerinin tüm çeşitlerini içermektedir. Bu süreç, mülteci hareketleri, yerinden edilmiş kişiler, doğduğu yerden ayrılmış kişiler ve ekonomik göçmenleri içerebilir. Göç, maddi ve sosyal durumlarını iyileştirmeye ihtiyacı olanları, ken- 
SSekil 1

Birleşik Krallık'taki uzun dönemli göçmenlerin yıllar itibari ile gösterimi

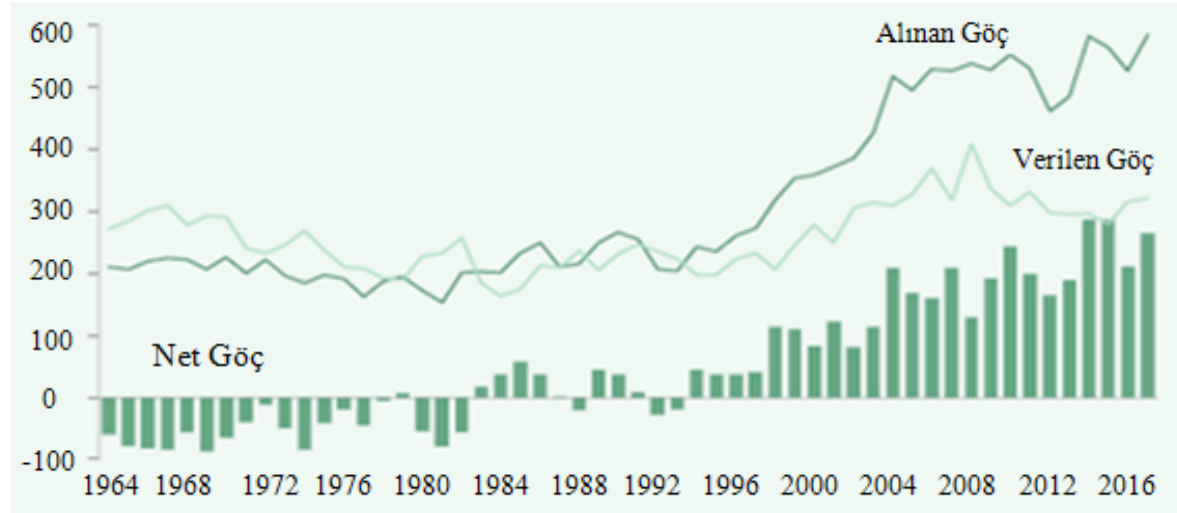

Kaynak: Sturge, G. (2018). Migration Statistics, House of Commons Library Briefing Paper, No: SN06077, s. 11.

dilerinin ve ailelerinin gelecekten beklentilerini arttırmak için başka ülkeye ve bölgeye göç eden kişileri kapsamaktadır (International Organization for Migration, 2013, s. 62-63). Literatürde, evrensel olarak kabul edilen göçmen tanımı bulunmasa da, Birleşmiş Milletler'in (BM) yaptığı göçmen tanımı birçok ülke tarafindan kabul görmektedir. Buna göre, yabancı bir ülkede bir yıldan fazla ikamet eden kişiler göçmen olarak ifade edilmektedir (Şemşit, 2018, s. 270).

Ekonomik açıdan bakıldığında göç, ülkeler arasındaki maaş farklılıklarından kaynaklanan işgücü hareketliliği olarak ifade edilebilir (Pekkala ve Kerr, 2011, s. 4 ve 15). Dolayısıyla, kişilerin, daha yüksek gelir elde etmek, daha iyi sosyal haklara ve yaşam standartına erişmek için bulunduğu yerleşim merkezinden bir başka yerleşim merkezine gitmesi, ekonomik göç kapsamında değerlendirilmektedir. Göçe sosyolojik açıdan yaklaşan Gordon Marshall, bireylerin veya grupların sembolik, coğrafi veya siyasi sınırların ötesine, yeni yaşam alanlarına ve topluluklara doğru hareketini göç olarak adlandırmıştır (Marshall, 1999, s.685). Bir başka yaklaşımla göç; "ne negatif ne de pozitif bir olgudur. Modern çağın ekonomik gelişmelerine, ulaşım ve iletişim sistemlerine, politik baskalarına ve bireysel dürtülere karşı gösterilen bir tepkidir" (Yılmaz, 2014, s. 1686). Göç, siyasi, ekonomik ve sosyal nedenlerle meydana gelebildiğinden, birçok disiplin tarafından çalışılmakta ve farklı tanımlamalara tabi tutulmaktadır. Bu yüzden, kişiler veya grupların daha iyi bir yaşam 
sürmek adına, ekonomik, siyasi veya toplumsal nedenlerle, bir yerleşim merkezinden başka bir yerleşim merkezine, iradesiyle (gönüllü) veya iradesi d1şında (zorla), kalıcı veya geçici şekilde veya yasal veya yasadışı yollardan göç edebilecekleri unutulmamalı ve buna göre sınıflandırmalar yapılmalıdır. Söz konusu sınıflandırmalara göre, çoğu gönüllü göçmen ekonomik nedenlerle göç etmekte, gönülsüz veya zorla göç edenler ise siyasi karışıklıklar, zulüm, baskı, şiddet olayları gibi nedenlere bağlı yer değiştirmektedir. Bu nedenle bir göçmen söz konusu sınıflandırmaların birinden diğerine kolayca geçiş yapa-

Tablo 1

2007-2017 yılları AB-28 işsizlik oranları

\begin{tabular}{|c|c|c|c|c|c|c|c|c|c|c|c|}
\hline & 2007 & 2008 & 2009 & 2010 & 2011 & 2012 & 2013 & 2014 & 2015 & 2016 & 2017 \\
\hline AB-28 & 7,2 & 7 & 9 & 9,6 & 9,7 & 10,5 & 10,9 & 10,2 & 9,4 & 8,6 & 7,6 \\
\hline Avro Alanı & 7,5 & 7,6 & 9,6 & 10,2 & 10,2 & 11,4 & 12 & 11,6 & 10,9 & 10 & 9,1 \\
\hline Belçika & 7,5 & 7 & 7,9 & 8,3 & 7,2 & 7,6 & 8,4 & 8,5 & 8,5 & 7,8 & 7,1 \\
\hline Bulgaristan & 6,9 & 5,6 & 6,8 & 10,3 & 11,3 & 12,3 & 13 & 11,4 & 9,2 & 7,6 & 6,2 \\
\hline Çek Cumhuriyeti & 5,3 & 4,4 & 6,7 & 7,3 & 6,7 & 7 & 7 & 6,1 & 5,1 & 4 & 2,9 \\
\hline Danimarka & 3,8 & 3,4 & 6 & 7,5 & 7,6 & 7,5 & 7 & 6,6 & 6,2 & 6,2 & 5,7 \\
\hline Almanya & 8,5 & 7,4 & 7,6 & 7 & 5,8 & 5,4 & 5,2 & 5 & 4,6 & 4,1 & 3,8 \\
\hline Estonya & 4,6 & 5,5 & 13,5 & 16,7 & 12,3 & 10 & 8,6 & 7,4 & 6,2 & 6,8 & 5,8 \\
\hline İrlanda & 5 & 6,8 & 12,7 & 14,6 & 15,4 & 15,5 & 13,8 & 11,9 & 10 & 8,4 & 6,7 \\
\hline Yunanistan & 8,4 & 7,8 & 9,6 & 12,7 & 17,9 & 24,5 & 27,5 & 26,5 & 24,9 & 23,6 & 21,5 \\
\hline İspanya & 8,2 & 11,3 & 17,9 & 19,9 & 21,4 & 24,8 & 26,1 & 24,5 & 22,1 & 19,6 & 17,2 \\
\hline Fransa & 8 & 7,4 & 9,1 & 9,3 & 9,2 & 9,8 & 10,3 & 10,3 & 10,4 & 10,1 & 9,4 \\
\hline Hurvatistan & 9,9 & 8,6 & 9,3 & 11,8 & 13,7 & 15,8 & 17,4 & 17,2 & 16,1 & 13,4 & 11,1 \\
\hline İtalya & 6,1 & 6,7 & 7,7 & 8,4 & 8,4 & 10,7 & 12,1 & 12,7 & 11,9 & 11,7 & 11,2 \\
\hline Kıbris & 3,9 & 3,7 & 5,4 & 6,3 & 7,9 & 11,9 & 15,9 & 16,1 & 15 & 13 & 11,1 \\
\hline Letonya & 6,1 & 7,7 & 17,5 & 19,5 & 16,2 & 15 & 11,9 & 10,8 & 9,9 & 9,6 & 8,7 \\
\hline Litvanya & 4,3 & 5,8 & 13,8 & 17,8 & 15,4 & 13,4 & 11,8 & 10,7 & 9,1 & 7,9 & 7,1 \\
\hline Lüksemburg & 4,2 & 4,9 & 5,1 & 4,6 & 4,8 & 5,1 & 5,9 & 6 & 6,5 & 6,3 & 5,6 \\
\hline Macaristan & 7,4 & 7,8 & 10 & 11,2 & 11 & 11 & 10,2 & 7,7 & 6,8 & 5,1 & 4,2 \\
\hline Malta & 6,5 & 6 & 6,9 & 6,9 & 6,4 & 6,3 & 6,4 & 5,8 & 5,4 & 4,7 & 4 \\
\hline Hollanda & 4,2 & 3,7 & 4,4 & 5 & 5 & 5,8 & 7,3 & 7,4 & 6,9 & 6 & 4,9 \\
\hline Avusturya & 4,9 & 4,1 & 5,3 & 4,8 & 4,6 & 4,9 & 5,4 & 5,6 & 5,7 & 6 & 5,5 \\
\hline Polonya & 9,6 & 7,1 & 8,1 & 9,7 & 9,7 & 10,1 & 10,3 & 9 & 7,5 & 6,2 & 4,9 \\
\hline Portekiz & 9,1 & 8,8 & 10,7 & 12 & 12,9 & 15,8 & 16,4 & 14,1 & 12,6 & 11,2 & 9 \\
\hline Romanya & 6,4 & 5,6 & 6,5 & 7 & 7,2 & 6,8 & 7,1 & 6,8 & 6,8 & 5,9 & 4,9 \\
\hline Slovenya & 4,9 & 4,4 & 5,9 & 7,3 & 8,2 & 8,9 & 10,1 & 9,7 & 9 & 8 & 6,6 \\
\hline Slovakya & 11,2 & 9,6 & 12,1 & 14,5 & 13,7 & 14 & 14,2 & 13,2 & 11,5 & 9,7 & 8,1 \\
\hline Finlandiya & 6,9 & 6,4 & 8,2 & 8,4 & 7,8 & 7,7 & 8,2 & 8,7 & 9,4 & 8,8 & 8,6 \\
\hline İsveç & 6,1 & 6,2 & 8,3 & 8,6 & 7,8 & 8 & 8 & 7,9 & 7,4 & 6,9 & 6,7 \\
\hline Birleşik Krallık & 5,3 & 5,6 & 7,6 & 7,8 & 8,1 & 7,9 & 7,5 & 6,1 & 5,3 & 4,8 & 4,4 \\
\hline
\end{tabular}

Kaynak: Eurostat, "Unemployment by Sex and Age- Annual Average", http://appsso.eurostat. ec.europa.eu/nui/show.do?dataset=une_rt_a\&lang=en, (06.09.2018). 


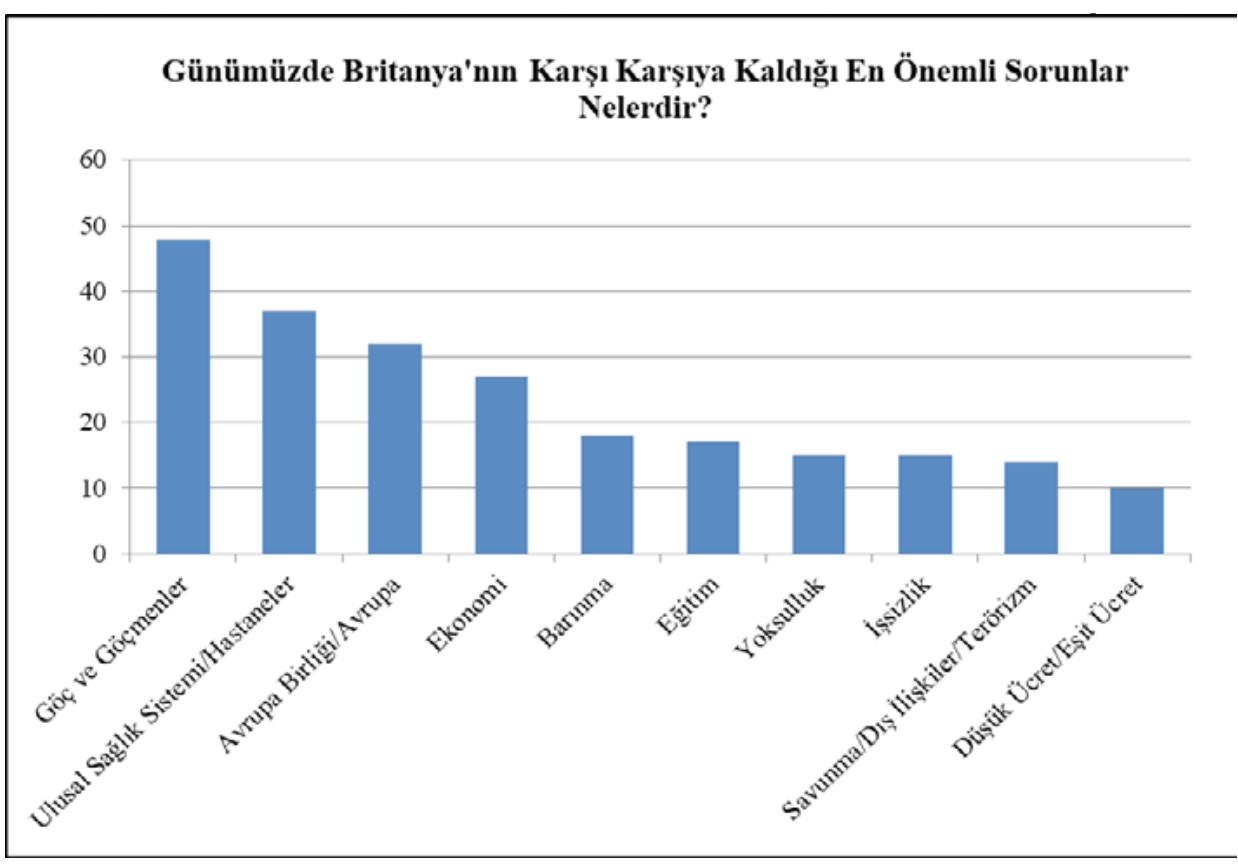

Kaynak: Ipsos Mori, “Ipsos MORI EU Referendum Prediction Poll”, https:/www.ipsos.com/ipsos-mori/en-uk/ipsos-mori-eu-referendum-prediction-poll, (Erişim Tarihi: 06.09.2018).

Soğuk Savaş'ın bitişi, göç dalgalarının çatışmalara ve siyasi istikrarsılılklara bağlı değişen yapısı, güvenlik kavramının yeniden tanımlanmasına neden olmuştur. Bu dönem, "göçler çağı" olarak da adlandırılmış, uluslararası sistemin değişen dinamiklerine ve küreselleşmenin artan etkisine bağlı olarak kitlesel göç dalgalarının artış göstermesi, Avrupa'da göçmenlere bakış konusunda yeni bir dönem yaratmıştır (Castles ark., 2014, s. 5). Özellikle 1990’larla birlikte, Doğu Avrupa ülkelerinden Batı'ya doğru yönelen göç dalgaları Birleşik Krallık'ta göçmenlere bakışı etkileyen önemli faktörlerden biri haline gelmiştir (Kaufmann, 2017, s. 3). Birleşik Krallık'a göç eden AB vatandaşlarının 1995 'te 1 milyon civarındayken, 2017'de 2.4 milyona yükseldiği kaydedilmiştir (Sturge, 2018, s. 17). Bu artışta özellikle Polonya ve Romanya gibi ül-

5 Bazı kaynaklarda düzensiz göç, "yasadışı” göç olarak ifade edilmektedir. Düzensiz teriminin kullanılmasının temel sebebi ise, yasadışı teriminin suçla ilişkilendirilmesi, bu terimin kullanımının göçmenin insan olmasından doğan haklarını göz ardı ettiği düşüncesinden kaynaklanmaktadır. Zulüm, savaş, siyasi çatışma, doğal afet gibi çevresel faktörler neticesinde güvenlik endişesiyle yasadışı yollarla göç etmek mecburiyetinde kalan birçok insanın yer değiştirme eylemi düzensiz göç altında ele alınmaktadır. 
kelerden 2000 sonrası genişleme dalgaları ile göç edenler büyük paya sahiptir (Özerim, 2017, s. 89). Göç edenlerin Birleşik Krallık’ı tercih etmelerinin arka planında ise en çok iş ve eğitim ile ilgili sebepler gelmektedir (Sturge, 2018, s. 17). Bu nedenle, referandum sürecine etkisi bakımından göçmenlere bakış değerlendirilirken, yalnızca AB dışındaki bölgelerden Birleşik Krallık’a göç edenler üzerinden bir değerlendirme yapmak yetersiz kalmaktadır. Çünkü Birleşik Krallık'ta mülteciler, ${ }^{6}$ sığınmacılar ${ }^{7}$ ve AB dışından göç edenlerin yanında, Avrupa vatandaşı olan göçmenlerin durumu da önemli bir tartışma konusu olarak gündemde yerini korumaktadır. Özellikle AB üye devletleri işsizlik oranları ve istihdam uygulamaları arasında kaydedilen farklılıklar nedeni ile iş bulmak amacı ile kendi ülkelerinden Birleşik Krallık'a göç eden Avrupa vatandaşları, referandum sürecinde ayrılık taraftarlarının sunduğu temel argümanlarda bir endişe unsuru olarak sunulmuştur (Özerim, 2017, s. 90). Aralık 2017 verilerine göre diğer AB üye devletlerinden gelen 3,8 milyon Avrupa vatandaşı Birleşik Krallık’ta yaşamaktadır. Söz konusu Avrupa vatandaşlarının durumu, ise Birleşik Krallık ve AB arasında belirlenecek yeni ilişki modeli için önemli bir gündem maddesidir.

Şekilde de görüldüğü üzere 1990'larla birlikte Birleşik Krallık’a yönelen uzun dönemli göçmenlerin sayısında ciddi bir artış olmuştur. Kitlesel göçlerin artı̧̧ göstermesine paralel bir şekilde güvenlik eksenli yaklaşımın artış göstermesi ve 11 Eylül 2001'de Amerika'da ve 7 Haziran 2005'de Britanya'da gerçekleşen terörist saldırıların neticesinde göçmenlere yönelik entegrasyon politikalarının yeniden gözden geçirilmesi oldukça önemli bir konuma sahip olmuştur (Kaufmann, 2017, s. 3). Göçün artık güvenlik tehdidi içinde görülmesi, kitlesel olabilen yapısı, ülkelerin kapasitelerini zorlayıcı olabilmesi, Birleşik Krallık dahil Avrupa'daki birçok ülkenin endişe duyduğu unsurlar halini almıştır (Mandacı ve Özerim, 2013, s.107).

6 Uluslararası alanda, mülteci hukukuna ilişkin temel belge niteliğinde olan 1951 tarihli Mültecilerin Hukuki Statüsüne İlişkin Sözleşme'ye göre mülteci: “Irkl, dini, tabiiyeti, belli bir toplumsal gruba mensubiyeti veya siyasi düşünceleri yüzünden, zulme uğrayacağından haklı sebeplerle korktuğu için vatandaşı olduğu ülkenin dışında bulunan ve bu ülkenin korumasından yararlanamayan, ya da söz konusu korku nedeniyle, yararlanmak istemeyen kişi" dir.

7 Sı̆̆ınmacı, kendi ülkesini terk edip başka bir ülkeye giden ve orada sığınma talebinde bulunan kişileri ifade etmektedir. Söz konusu ülkede yapılan sığınma başvurularının değerlendirilmesinin neticesinde, uluslararası ve iç hukuk kurallarına uygun bir şekilde sığınma hakkı verilen kişiler mülteci statüsüne erişmektedir. Eğer sığınma başvurusuna olumsuz geri dönüş yapılırsa, söz konusu başvuruyu yapan kişi veya kişiler, ülkeyi terk etmek mecburiyetindedir. 
Çok kültürlülüğün bir tehlike olarak tanımlanmaya başlaması, göçmen karşıtlığının medyanın ve siyasi aktörlerin söylemleri ile geniş bir tabana yayılması, Brexit sürecindeki itici faktörler arasındadır. Ayrıca Birleşik Krallık’taki "yerli beyaz nüfus (native white population)" olarak ifade edilen bazı grupların işsizlik ve konut kıtlığı gibi sorunlar yaşamaları neticesinde sorumlu olarak göçmenleri gösteren bir tutum içinde bulunmaları, Birleşik Krallık’ta göçmen karşıtı söylemler benimseyen partileri destekleyenler açısından bir açıklama sunmaktadır (Tahir, 2017, s. 85). Bu söylemlerin şekillenmesinde rol oynayan faktörlerden biri de şüphesiz ki 2008 krizidir.

Tabloda da görüldüğü üzere 2008 krizinin ardından özellikle işsizliğin azaltılması ve istihdam yaratılması konusunda birçok $A B$ ülkesinden daha iyi performans gösteren Birleşik Krallık’ta, yine de işsizlik sorunu göçmenlerle bağdaştırılmış ve bazı gruplar tarafından göçmenler hedef gösterilmiştir (Yavuzaslan, 2017, s. 235). Özellikle, işsizlik oranları yüksek olan diğer üye devlet vatandaşlarının daha iyi koşullara sahip olması nedeni ile Birleşik Krallık'a göç ettikleri savı Avrupa şüphecilerinin söylemlerine yer eden önemli bir husustur. Buna göre, Birleşik Krallık’taki bazı parti söylemleri, işsizlik ve konut kıtlığı konularında göçmenlerle ilişki kurulması yolu ile şekillendirilmiştir (Coulter, 2016, s.197).

AB referandumu öncesinde 3-13 Haziran tarihleri arasında Ipsos Mori'nin gerçekleştirdiği bir alan araştırmasının sonuçlarına göre "Günümüzde Britanya'nın karşı karşıya kaldığ 1 en önemli sorunlar nedir?” sorusuna İngilizler tarafindan verilen cevaplara göre, birinci sırada göç ve göçmenler (\%48), ikinci sırada ulusal sağlık sistemi (\%37), üçüncü sırada Avrupa Birliği (\%32), dördüncü sırada ekonomi (\%27) ve beşinci sırada barınma (\%18) başlıkları önemli sorunlar olarak sıralanmıştır (Ipsos Mori, 2018, s. 1). İngilizler tarafından göçmenlerin en önemli sorun olarak görüldügünü resmeden bu araştırma, Birleşik Krallık’taki göçmen karşıtı söylemlerin niçin Brexit sürecini etkileyen temel faktörlerden biri olduğunu açıklayan bir referans sunmaktadır. Referandumdan sonra yapılan başka bir araştırmaya göre ise, egemenlik ile ilişkili endişeler ve göçmen karşıtlığı, $\mathrm{AB}$ referandum sürecinde kampanyaları şekillendiren temel faktörler olarak gözlemlense de, oy verenler nezdinde sisteme olan güvensizliğin temel unsurlardan biri olduğu üzerinde durulmuştur. Bu noktada, birçok İngiliz'in (doğuştan vatandaşlı̆ga 
sahip olanların), Birleşik Krallık'ta kendi işlerinin göçmenler tarafından ellerinden alındığ 1 ve kendilerini ülkelerinde yabancı hissettikleri gerekçeleri ile referandumda ayrılma taraftarlarını desteklediği tespit edilmiştir. Fakat burada AB'den ayrılma ve kalma yönünde oy verenlerin demografi ve tutum anlamında tek bir profil altında kategorize edilmemesi gerektiği de eklenmelidir (Ipsos Mori, 2017, s. 10). Araştırma ayrıca, referandumdan sonra göç ve göçmenler konusunun daha az endişe unsuru hale geldiğini belirtmekte, fakat kamuoyunda hala Birleşik Krallık'a yönelen göçün azaltılması görüşünün hakim olduğunun da altını çizmektedir. Buna göre, hala 10 İngiliz'den 6'sının Birleşik Krallık'a yönelen göçün azaltılması gerektiği yönünde tutum sergilediğinden bahsedilmektedir (Ipsos Mori, 2017, s. 2-3). Brexit öncesi ve sonrasında yapılan araştırmalar değerlendirildiğinde, referandum sonrasında göç ve göçmenlere bakış konusunda bir yumuşama süreci yaşandığı gözlemlense de Birleşik Krallık'a yönelen göç İngilizler için hala ciddi bir endişe unsurudur. Bir başka araştırmaya göre ise, İngilizlerin Birleşik Krallık’a yönelen göçü bir endişe unsuru olarak tanımlamalarındaki başlıca sebepler, ( $b a$ rınma ve konut tesis edilmesi hususları dahil) göçmenlerin kamu hizmetleri üzerinde oluşturduğu yük, kültürel sebepler, entegrasyon problemleri ve suç oranındaki artış şeklinde sıralanmaktadır (Özerim, 2017, s. 89).

\section{Birleşik Krallık’ta Göçmen Karşıtı Söylemler, UKIP Örneği ve Brexit Süreci}

2000'li yıllardan itibaren Avrupa ülkelerinin parlamentolarında göçmen karşıtı söyleme sahip partilerin güç kazanmaya başlaması, göçün güvenliği tehdit eden bir unsur olarak sunulmasında önemli rol oynamıştır (Mandacı ve Özerim, 2013, s. 106). Avrupa ve özellikle Birleşik Krallık’ta göç ve güvenlik arasında bir ilişkinin sunulmasında etkili olan diğer önemli olaylar ise, 2001'de İngiltere'nin kuzeyinde Oldham, Burnley ve Bradford'da sivil karışıklıkların yaşanması ${ }^{8}$, Londra ve Madrid'in bombalanması, özellikle Orta ve Doğu Avrupa ülkelerinin AB'ye üye olması ile birlikte Birleşik Krallık'a yönelen Avrupalı göçmen sayısında artış yaşanması, küreselleşme ile birlikte

8 Söz konusu olaylar, yerel halk ile (çoğunluğu Pakistanlı ve Bangladeşli olan) Müslüman-Güney Asyalılar arasında gerçekleşen etnik çatışmalar adı altında değerlendirilmektedir. Bu çatışmalar sonucunda 395 kişi tutuklanmış ve 12 milyon dolar tutarında zarar meydana gelmiştir. Çatışmalar, İngiltere'deki ırkçı yaklaşımın örnekleri arasına girerek büyük yankı uyandırmış ve İngiltere'nin çokkültürlülük eksenli yaklaşımının sarsılmasında ve tartışılmasında oldukça etkili olmuştur. 
göç türlerinin çeşitlenmesi ile daha iyi bir yaşama sahip olmak isteyenlerin Avrupa kıtasına ve hatta Birleşik Krallık'a göç etme isteklerinin yoğunlaşmas1 olarak ifade edilebilir (Tahir, 2017, s. 76).

Son dönemlerde, Avrupa'daki aşırı sağ partiler, bütünleşme süreci ile ilgili söylemlerine ilişkin olarak Avrupa şüpheciliği (euroskeptic) ve karşıtllı̆ı (euroreject) olmak üzere iki eksen üzerinden değerlendirilirken, bu süreçte özellikle 2008 krizinin etkisiyle göçmenleri daha da güvenliği tehdit edenler olarak tanımlamaları ve göçmen karşıtlığı üzerinden söylem geliştirmeleri ile dikkat çekmektedir (Pirro ve Kessel, 2017, s. 405-407). 2000-2017 dönemine bakıldığında 2008 krizinin, popülist radikal sağ partilerin $\mathrm{AB}$ bütünleşmesine karşıt veya şüpheci söylemlerini tetikleyerek daha da arttırdığını ve göçmen karşıtlığını 2008 sonrası dönemde yeniden konumlandırdığı söylenebilir (Pirro ve Kessel, 2017, s. 405).

Ayrıca 2011 yılında patlak veren Suriye İç Savaşı'nın yarattığı yerinden edilmişlik sorunu, Avrupa'ya yönelen Suriyelilerin yeni bir güvenlik krizi olarak tanımlanmasına neden olmuştur. Göçün güvenlik ekseninde ele alınması bu dönemde yeni bir oluşuma işaret etmese de, bu anlayışın Suriyelilerin $\mathrm{AB}$ için tehdit oluşturacağı yönünde somut bir süreci yaratması oldukça ilginçtir. Dolayısı ile Suriyelilerin oluşturduğu kitlesel bir akının Avrupa güvenlik yaklaşımında karşılanma şekli, üye devletlerde farklılık göstermiş ama bir yandan da popülist söylemlerin ivme kazanmasında itici faktör görevi görmüştür. Brexit sürecinde de göçmen karşıtı söylemler oldukça etkili olmuş ve söz konusu kronolojik sürece bağlı göçmen karşıtlı̆̆ 1 da artış göstermiştir.

Referandum sürecinde parti kampanyaları için oluşturulan argümanlarda en fazla yapılan vurgulardan biri Birleşik Krallık’ın aldığı göç ile ilişkilidir. Öncelikle 2010-2016 yılları arasında Birleşik Krallık Başbakanlığı görevini üstlenen Muhafazakar Parti Genel Başkanı David Cameron'un benimsediği söylem üzerinde durmak oldukça önemlidir. Cameron, 2010 seçimleri öncesinde Birleşik Krallık'a gelen net göçmen sayısının büyük oranda düşürüleceği, 1990'lardaki seviyeye çekilmesi için çaba sarf edileceği üzerinden bir söylem benimsemiştir (Menon, 2017, s. 123). Nitekim 2011'de sinır kontrollerinde titiz davranılmas1 ve $A B$ vatandaşı olmayanlara vize verilmesi anlayışında daha sıkı bir politikaya başvurulması yoluyla, Birleşik Krallık'a yönelen göç oranı düşmeye başlamıştır (Levi ark., 2017, s. 10). Fakat, bu dönemde süren ekonomik ve mali krizin etkileri, Avrupa genelinde göç akışı konusunda bir artış yaratımıştır. Bu artışın ya- 
şanmasında ayrıca, AB'ye 2007 yılında yeni üye olarak kabul edilen Romanya ve Bulgaristan ile işçilerin serbest dolaşımının sağlanması için imzalanan geçiş süreci antlaşmalarının tamamlanması ve bu bölgelerden diğer $\mathrm{AB}$ ülkelerine göçün başlamış olması oldukça etkili olmuştur (Levi ark., 2017, s. 10).

Tüm bunların sonucunda, göçmenlerin sayısında umulduğu gibi bir düşüş gözlemlenmemiş ve David Cameron'un vaad ettiklerini yerine getirememesi "başarısızlık" adı altında değerlendirilerek Avrupa şüphecilerinin elini kuvvetlendirmiştir. Özellikle Niegel Farage, David Cameron'un sözünü yerine getiremediği savından hareket etmiş ve AB'ye üye olduğu sürece Birleşik Krallık'ın kendi sınırlarını kontrol etmekten uzak olduğu üzerinden söylem geliştirmiştir (Levi ark., 2017, s. 10). Söz konusu söylemlerin şekillendiği dönem ise, göçün bir sorun olarak söylemlere yansitılmasının Brexit sürecinden daha önceye dayandığını kanıtlamaktadır. Niegel Farage'ın liderlik ettiği, Avrupa şüphecisi ve göçmen karşıtı söylemlere sahip UKIP'in Birleşik Krallık'ta güçlenmeye başlamasından endişe duyan David Cameron'un oy kaybetmeme yaklaşımından hareketle 2013 yılında referandum sözü vermesi ise 2015 genel seçimlerinde Cameron'ın kazanmasında etkili bir hamle olmuştur (Applebaum, 2017, s. 53).

Göçmenler üzerinden geliştirilen söylemler Birleşik Krallık için sorun haline gelen yeni bir olgu olmamasına rağmen, göçün bir sorun olarak Birleşik Krallık referandum süreci için düzenlenen kampanyaların odağına yerleştirilmesi ve süreci yöneten temel unsurlardan biri haline gelmesi farklı bir bakış açısını sunmaktadır (Meleady ark., 2017, s. 799). Ayrılık taraftarları ve AB'de kalma taraftarları olmak üzere iki kampın oluşması ile gerçekleşen referandum kampanyalarında en öne çıkan yarış ise Muhafazakar Parti ve UKIP arasında gerçekleşmiştir (Virdee ve McGeever, 2017, s. 3). Çok kültürlülük anlayışına tamamı ile karşı çıkan ve göçmen karşıtlığını benimseyen UKIP, Niegel Farage önderliğinde, hem Birleşik Krallık hem de Avrupa genelinde benimsenen aşırı sağ söylemi temsil etmiştir (Tahir, 2017, s. 83). Farage, göçmenler için uygulanan entegrasyon politikalarında benimsenen çok kültürlülük yaklaşımına ilişkin olumsuz bir söylem geliştirerek, bu felsefenin uygulandığı her yerde başarısız olduğu görüşünü benimsemiştir (Tahir, 2017, s. 83-84). Bu başarısızlığın Birleşik Krallık için de geçerli olduğunu öne süren Farage, göçün kontrol altına alınması gerektiği ve bunun için de çok kültürlülük adı altında geliştirilen politikaların terk edilmesine ihtiyaç olduğu üzerinde durmuştur (Tahir, 2017, s. 85). 
Başbakan David Cameron ise, AB'de kalma taraftarı olan Muhafazakar Parti adına söylemlerini daha çok ekonomik argümanlar üzerinde yoğunlaştırmıştır (Powell, 2017, s.226). Fakat bunu yaparken, Britanya'nın AB'de daha güçlü olacağına dair bir yaklaşım benimsemekten uzak durmuştur. Bu ekonomik argümanlar ise, Birleşik Krallık'ın AB'den ayrılma kararı almasının doğurabileceği tehditler üzerinden desteklenmiş ve göçün kontrol altına alınmasına ilişkin sert taahhütlerle şekillendirilmiştir. Ayrıca Avrupa Birliği bütçesinden ayrılmanın Birleşik Krallık için bir başka tehdit unsuru olabileceğine dair savlar da David Cameron'un önderliğinde yürütülen kampanya sürecinde yer almıştır (Powell, 2017, s.232). Kampanya sürecinde AB'den ayrılma ve kalma taraftarlarının göç ve göçmenlere karşı olumsuz bir yaklaşım sergileme konusunda kimi zaman ortak paydada birleştikleri söylenebilir. Bu durum, David Cameron ve Niegel Farage'ın söylemleri için de geçerlidir. Bu iki lider her ne kadar kampanya sürecinde farklı kamplarda birbirleri ile mücadele etse de, göçmenlere bakış söz konusu olduğunda söylemleri birbirine yaklaşmıştır. Dolayısı ile göçmen karşıtlı̆̆ı, referandum kampanya sürecinde hem medya hem de siyasi partiler aracılığı ile en etkili araç olarak kullanılmıştır. Bu anlamda, Birleşik Krallık referandumu kampanya süreci, aşırı sağ söylemlerin artış göstermesi, popülizmin etki alanını arttırması, göçmen karşıtlığının seçimlerde taban kazanmak için en önemli araçlardan biri haline gelmesi hususlarının bir arada toplandığı önemli bir örnek sunmaktadır.

\section{Sonuç}

Birleşik Krallık'ın AB'den ayrılma yönünde karar alması Avrupa bütünleşmesinin geleceğine ilişkin yeni senaryoların tartışılmasına zemin hazırlamıştır. Geçmişten günümüze Birlik politikalarındaki sınırlı desteği nedeni ile "Avrupa şüphecisi”" ve "izole üye" kavramları ile eşleştirilen Birleşik Krallık'ın gerçekleştirdiği referandum sonucunda AB'den ayrılma yönünde karar alması beklenmeyen bir durumu tanımlamamaktadır. Avro Bölgesi, adalet ve içişleri ve Schengen Bölgesi gibi alanlarda üye devletler arasında dayanışma kültürünün geliştirildiği Birlik'te, üyeliğinden bu yana Birleşik Krallık politikalarının dayanışma kültüründen uzaklaşarak ayrışması, Avrupa şüpheciliği ekseninde değerlendirilmiştir. $\mathrm{Bu}$ yüzden Birleşik Krallık AB referandumu sonucunda ayrılık taraftarlarının ağır basması, birçok üye devlet nezdinde şaşırtıcı bir tablo çizmemektedir.

Avrupa şüphecilerinin kazananlar olarak ifade edildiği referandum süreci ve sonrasında etki eden itici faktörler, Avrupa bütünleşmesinin geleceği için 
risk oluşturmaktadır. Referandum sürecinde özellikle göçmenlerin güvenliği tehdit edenler olarak konumlandırılması yalnızca Birleşik Krallık'ta yaşanan bir soruna işaret etmemekte, Avrupa'daki birçok siyasi partinin söylemine yer etmesi nedeni ile bütünleşmenin derinleşmesi önünde engel teşkil etmektedir. Göçmen karşıtlığı AB'deki birçok partinin söyleminde yer ederken, Avrupa kimliği ve vatandaşlığı vurguları açısından da bir tartışma alanı yaratmaktadır. Özellikle Birleşik Krallık örneğinde aşırı sağ söylemin temsilcilerinden Niegel Farage'ın çok kültürlülük karşıtı söylemleri ve Orta ve Doğu Avrupa ülkelerinden gelen göçmenleri kendi sistemlerinde bir tehdit olarak tanımlaması buradaki önemli tartışmalardan biridir. AB sisteminde "Avrupa vatandaşlığı" ayrımcılık yapmama esası altında değerlendirilse de, bu hükmün üye devletlerdeki tüm politik gruplar tarafından içselleştirilmediği bir gerçektir.

Birleşik Krallık referandumu kampanya sürecinde göçmen karşıtlığ popülist söylemlerin merkezine yerleştirilmiştir. Göç ve göçmenlerin "kriz" adı altında değerlendirilmeye başlandığı ve güvenlik için bir tehdit olarak algılandığı bir Avrupa konjonktüründe, aşırı sağın söylemlerine göçmen karşıtlığını yerleştirerek etki alanını genişletmesi, Avrupa bütünleşmesi açısından endişe vericidir. Ayrıca Birleşik Krallık örneğinde de olduğu gibi siyasi partiler ve liderlerinin söylemlerinin kamuoyundan bulduğu destek, diğer partilerin söylemlerini de belirleyebilmektedir. Bu anlamda Niegel Farage ve David Cameron'un söylemlerinin çarpıştığı bir referandum kampanyası sürecinde, Cameron'un söylemlerine göç ve göçmenlere olumsuz bakışın yerleştirilmiş olması popülizmin etki alanı ile de ilişkilidir.

Birleşik Krallık referandum sürecini belirleyen temel faktörlerden birinin söylemlerde yer eden göç ve göçmen karşıtlığının oluşu, Avrupa Birliği için önemli bir ipucu sunmaktadır. Çünkü göçmen karşıtlığı faktörü yalnızca Birleşik Krallık siyasi arenasında etki alanını genişletmemiş, bugün AB'nin birçok ülkesinde endişe verici bir boyuta ulaşmıştır. AB'nin başa çıktığı sorunlar arasında sayılan aşırı sağın yükselişi, göçmenlere ve çok kültürlülüğe bakış anlamında Avrupa değerleri ile çatışan bir paradoksal yapı doğurmaktadır. Bu doğrultuda Birleşik Krallık'ın AB'den ayrılma yönünde karar aldığı referandum süreci ve sonrası, göçmen karşıtı söylemler benimseyen aşırı sağın etki alanını ne derece genişletebileceği hususunda somut bir çıktı sunmaktadır. 


\section{Kaynakça/References}

Applebaum, A. (2017). Britain After Brexit: A Transformed Political Landscape. Journal of Democracy, 28(1), 53-58.

Bakkalcı, C. (2008). Küreselleşme, Bölgesel Entegrasyonlar, Ülkelerüstü Kurumlar, Entegrasyon Teorisi ve Avrupa Birliği. Nobel Kitapevi.

Castles, S., Haas, H., Miller M. (2014). The Age of Migration (Fifth Edition). Palgrave Macmillan.

Coulter, S. (2016). The UK Labour Market and the Great Recession. Myant, M., Theodoropoulou, S., Piasna, A. (Ed.) Unemployment, Internal Devaluation and Labour Market Deregulation in Europe, 197-227. European Trade Union Institute.

Daddow, O. (2013). Margaret Thatcher, Tony Blair and the Euroskeptic Tradition in Britain. The British Journal of Politics and International Relations, 15, 210-227.

European Commission. (2017). White Paper on the Future of Europe and the Way Forward: Reflections and Scenarios for the EU 27, Erişim Tarihi: 12.04.2018, https://ec.europa.eu/ commission/white-paper-future-europe-reflections-and-scenarios-eu27_en

Epstein, R., Jacoby, W. (2014). Eastern Ten Years on: Transcending the East-West Divide?. Journal of Common Market Studies, 52, 1-16.

Ermağan, İ. (2012). Avrupa Birliği Entegrasyonunda Şüphecilik. Girişimcilik ve Kalkınma Dergisi, 7(2), 2, 145-168.

Eurostat, (2018). "Unemployment by Sex and Age- Annual Average”, http://appsso.eurostat.ec.europa.eu/nui/show.do?dataset=une_rt_a\&lang=en, (06.09.2018).

Goodwin, M., Heath, O. (2016). The 2016 Referandum, Brexit and the Left Behind: An Aggregate-level Analysis of the Result. The Political Quarterly, 87(3), 323--332.

Sturge, G. (2018). Migration Statistics, House of Commons Library Briefing Paper, No: SN06077, 1-39.

International Organization for Migration. (2011). Glossary on Migration. (ed. Richard Perruchoud, Jillyanne Redpath-Cross), Second Edition.

Ipsos Mori. (2016). Ipsos MORI EU Referendum Prediction Poll, Erişim Tarihi: 06.09.2018, https://www.ipsos.com/ipsos-mori/en-uk/ipsos-mori-eu-referendum-prediction-poll.

Ipsos Mori. (2017). Shifting Ground: 8 Key Findings from A Longitudinal Study on Attitudes Towards Immigration and Brexit, Erişim Tarihi: 07.09.2018, https://www.ipsos.com/ sites/default/files/ct/news/documents/2017-10/Shifting\%20Ground_Unbound.pdf.

Kaufmann, E. (2017). Can Narratives of White Identity Reduce Opposition to Immigration and Support for Hard Brexit? A Survey Experiment. Political Studies, Erişim Tarihi: (13.04.2018), http://journals.sagepub.com/doi/abs/10.1177/0032321717740489, 1-16.

Köroğlu, N., Çendek, S. (2015). Toplumsal Güvenlik, Kimlik, Bütünleşme Bağlamında Avrupa Şüpheciliği: Cameron Dönemindeki Avrupa Şüpheciliğinin İçerik Analizi. Akademik Incelemeler Dergisi, 10(2), 191-216. 
Levi, E., Mariani, R., Patriarca, F. (2017). Hate at First Sight? Dynamic Aspects of the Electoral Impact of Migrations: The Case of the UK and Brexit. University of Sussex Science Policy Research Unit Working Paper Series, 1-36.

Ling, Jin. (2016). Will Brexit Matter: A Probe into Its Reasons, Influences and Tendencies. China International Studies, 66, 66-85.

Marshall, G. (1999). Sosyoloji Sözlüğü. Bilim Sanat Yayınları.

Meleady, R., Seger, C., Vermue, M. (2017). Examining the Role of Positive and Negative Intergroup Contact and Anti-immigrant Prejudice in Brexit. British Journal of Social Psychology, 56(4), 799-808.

Mandacı, Nazif ve Özerim, Gökay. (2013). Uluslararası Göçlerin Bir Güvenlik Konusuna Dönüşümü: Avrupa'da Radikal Sağ Partiler ve Göçün Güvenlikleştirilmesi, Uluslararası İlişkiler Dergisi, 10, 105-130.

Menon, A. (2017). Why the British Chose Brexit: Behind the Scenes of the Referandum. Foreign Affairs, 96, 122-126.

Nugent, N. (2004). Previous Enlargement Rounds, Neil Nugent (Ed.), European Union Enlargement. Palgrave Macmillian.

Özerim, G. (2017). Göç Konusunun Birleşik Krallık’ta AB Referandumu Sürecindeki Yeri, Erol Esen ve Duygu Şekeroğlu (Ed.), BREXIT-Elveda Avrupa Ingiltere 'nin AB'den Ayrllmasından Sonra Avrupa Bütünleşmesi ve Türkiye $\square$ AB İlişkilerinde Fırsatlar ve Tehditler, Siyasal Kitapevi.

Pekkala, Sari ve R. Kerr, William. (2011). Economic Impacts of Immigration: A Survey, Harvard Business School Working Paper 16736, 1-37.

Pirro A., Kessel, S. (2017). "United in Opposition? The Populist Radical Right's EUPessimism in Times of Crisis". Journal of European Integration, 39(4), 145-168.

Powell, K. (2017). Brexit Positions: Neoliberalism, Austerity and Immigration-the (Im) possibilities of Political Revolution. Dialectical Anthropology, 41(3), 225-240.

Scuira, L. (2017). Brexit Beyond Borders: Beginning of the EU Collapse and Return to Nationalism. Journal of International Affairs, 70(2), 109-123.

Startin, N. (2015). Have We Reached A Tipping Point? The Mainstreaming of Euroscepticism in the UK. International Political Science Review, 36(3), 311-325.

Serricchio, F., Tsakatika, M., Quaglian L. (2013). Euroskepticism and Global Financial Crisis. Journal of Common Market Studies, 51(1), 51-64.

Sutherland, P. (2016). Brexit: What Does it Mean for Europe?. An Irish Quarterly Review, 105, 309-318.

Şemşit, S. (2018). Avrupa Birliği Politikaları Bağlamında Uluslararası Göç Olgusu ve Türleri: Kavramsal Bakış. Yönetim ve Ekonomi Dergisi, 25(1), 269-289.

Taggart, P. (1998). A Touchstone of Dissent: Euroscepticism in Contemporary Western European Party Systems. European Jornal of Political Research, 33, 363-388. 
Tahir, J. (2017). Multiculturalism: A Comparative Study of British Political Parties. Journal of European Studies, 33(1), 71-89.

Virdee, S., McGeever, B. (2017). Racism, Crisis and Brexit. Ethnic and Racial Studies, https:// www.tandfonline.com/doi/full/10.1080/01419870.2017.1361544, (08.05.2018), 1-18.

Whelan, D. (2018). Assessing the Reasons and Options for Brexit: A Defence of the UK's Decision to Leave the EU. North East Law Review, 1, 1-5.

Yavuzaslan, K. (2017). Brexit Yol Ayrımında Avrupa Birliği Sosyal Bütünleşme Çabalarına İnovatif Bir Yaklaşım: Sosyal İnovasyon, Afyon Kocatepe Üniversitesi Sosyal Bilimler Dergisi, 19(1), 225-250.

Yılmaz, A. (2014). Uluslararası Göç: Çeşitleri, Nedenleri ve Etkileri, Tuskish Studies, 9, 1685-1705. 